\title{
A KERESZT MINT ÉLETFA ${ }^{1}$
}

\author{
RABB PÉTER* \\ építész, egyetemi tanársegéd
}

A szepességi Zsegra középkori templomában csodálatos falképek láthatók. ${ }^{2}$ A közel hétszáz esztendeig későbbi átfestések rétegei alatt rejtőző - és így általuk szerencsésen megőrzött - képek több szempontból is különleges alkotások. Elsősorban persze azért, mert egyátalán megmaradtak, hiszen a XVI. század első feléből nagyon kevés festett falkép ismeretes, másrészt pedig a szokásostól eltérő ábrázolásmód miatt is. A Jézus életének állomásait bemutató képek telis-tele vannak szimbólumokkal, allegórikus alakokkal, sokkalta mélyebb - pontosabban magasabb - értelmet adva az ábrázolt jeleneteknek, mint azt első látásra gondolnánk. Közülük is a megfeszített Krisztus képét tartom a legizgalmasabbnak, s a továbbiakban az ezzel kapcsolatos gondolataimat szeretném megosztani az olvasóval.

A nagyjából négyzet alakú, széles szalaggal keretezett, vörösesbarna hátterú kép leghangsúlyosabb eleme a középen - nincs jobb szó rá - tornyosuló keresztfa, amely, mint valamiféle középtengely, szinte kettészeli a képet. Nemcsak mérete, hanem formája és rendeltetése is figyelemre méltó. Szembetűnő, hogy Krisztus egy stilizált, de valóságos fán függ, s rövid magyarázat után az is belátható, hogy e fa sokkal inkább összeköti a képmezőket, mintsem szétválasztaná. Hogyan lehetséges mindez?

* Budapesti Múszaki és Gazdaságtudományi Egyetem, Építészmérnöki Kar, Építészettörténeti és Múemléki Tanszék. 1111 Budapest, Müegyetem rkp. 3. K. II. 60. Tel.: 463-1330; fax: 463-1638; e-mail: rabbpeter@freemail.hu

${ }^{1}$ Az elhangzott és itt olvasható tanulmány nem tartozik a szorosan vett kutatómunkámhoz, ellenkezőleg: kifejezetten arra törekedtem, hogy attól független témát válasszak, ezzel is tisztelegve kedves tanárom előtt. Talán e mentegetőző sorok megmagyarázzák az érdeklődő olvasónak munkám tudományos és formai hiányosságait.

${ }^{2}$ A zsegrai képek tudományos feldolgozását Radocsay Dénes végezte el, munkájának eredményét - gazdag forrásjegyzékkel kiegészítve - két könyvében is közzétette. Radocsay 1954. 240-242. XXXVI-XXXVII. tábla, Radocsay 1977. 174-177. 88-90. kép 


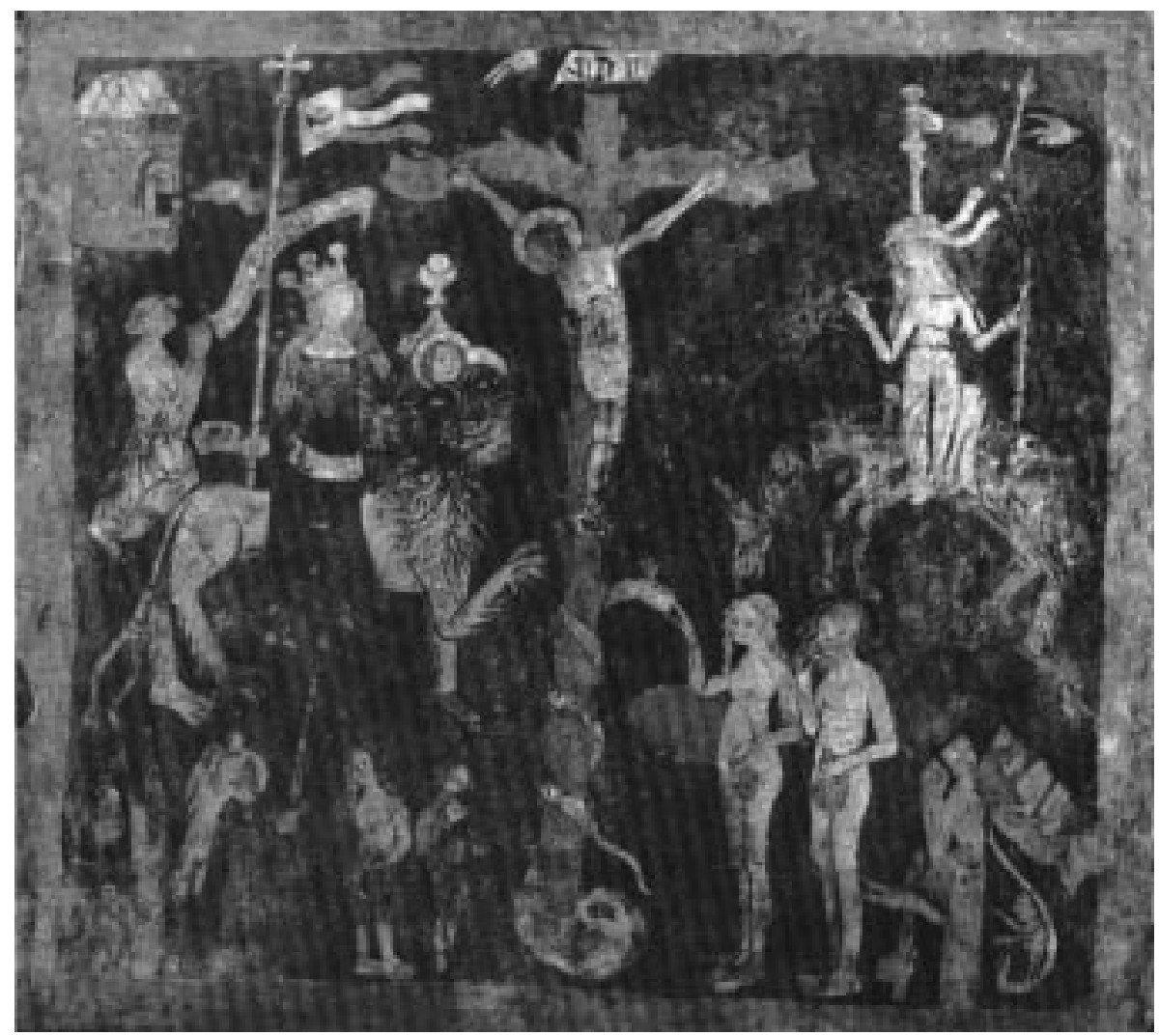

A zsegrai templomban látható Kálvária-jelenet részlete (Radocsay 1977. 88. kép)

Nos, a kép valóban két különböző részből áll, ezek azonban nem a keresztfa két szemben lévő oldalán vannak, hanem egymás fölött. Az alakok elhelyezkedése alapján ugyanis egyértelműen két alapsík, ebből következően két képsík látható.

Az alsó mező a bűnbeesést és annak következményét ábrázolja. A kereszt balján Ádám és Éva éppen elfogyasztja a tiltott gyümölcsöt a fára tekeredő kígyó csábításának engedve, míg a másik oldalon a kiüzetés jelenete szerepel, amint az Úr angyala lángoló pallossal kikergeti a Paradicsomból a bünös emberpárt.

A felső mezőben - pontosabban felső szinten - a Megváltó két oldalán két nőalak jelenik meg, jellegzetes szereplőiként a hasonló témájú ábrázolásoknak. Krisztus jobb - értsd: jobbik - oldalán Ecclesia ül. A hatalmat jelképező oroszlán hátán ,vonul be”, fején a dicsőség koronája, egyik kezében a győzelem keresztes zászlaja, a másikban pedig egy serleg telve Krisztus összegyüjtött vérével. Ez a nőalak nem más, mint a dicsőséges egyház, mely a szent vér birtokosaként egyedül alkalmas a szentségek kiszolgáltatására. A bal oldalon egy megbokrosodott sza- 
máron egy bekötött szemű nőalak látható, amint az Úr keze éppen leszúrja. Ő Synagoga, a Messiást fel nem ismerő zsidóság - és sorsának - allegóriája. E két szimbolikus alak a keresztábrázolások gyakori kísérője volt, különösen a korai századokban. ${ }^{3}$

A képmezők elrendezése, egymáshoz viszonyított elhelyezkedése egyátalán nem a véletlen múve, hanem tudatos, többlettartalmat kifejezni akaró művészi szándék megvalósulása. Azzal ugyanis, hogy a mezők egymás fölött vannak, nemcsak az események idősíkjai különülnek el egymástól -ami régebbi, az mélyebben van-, de egyértelmủ rangsort is kifejeznek, hiszen a magasabbrendủ csakugyan az alacsonyabbrendủ fölött áll. Ezeket a mezőket köti össze a keresztfa. Az alsó, ősibb és mélyebb síkon, az eredendő bün világában mint a tiltott tudás fája szerepel, míg a magasabb szférában a megváltás jelképévé válik.

De lehetséges-e ilyen, egymással szögesen ellentétes fogalmak, mint az ősbün és a megváltás egy jelképben történő összekapcsolása. Nos, ha abból indulunk ki, hogy e két fogalom voltaképpen ugyanannak a folyamatnak a része, kiinduló, illetve végállomása, már kevésbé tarthatjuk ezt a képzettársítást szokatlannak. Nem volt már az a korai egyházatyák számára sem, mondván:

„Mert amiképpen Ádámban mindnyájan meghalnak, azonképpen a Krisztusban is mindnyájan megelevenittetnek."

(1Kor 15,22)

„A megtestesült Ige a fán függve eltörölte a fán elkövetett engedetlenséget."

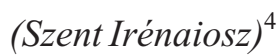

Tehát voltaképpen a tudás fája azonos Krisztus keresztfájával, amely pedig az élet fája. Ezt persze sokkal költőibben fogalmazza meg a vers:

\section{„, Ezt a fát az összülöknek Alkotónk jelölte meg, mert halált a végzetes fa almájával ettenek; Azt akarta, fának átkát Fának titka törje meg." (Pange Lingua 2. vsz. Sik sándor forditása) ${ }^{5}$}

Fának átka? Fának titka? Életfa? Véletlen egybeesés csupán, hogy ennyi helyütt találkozunk velük, vagy a fák csakugyan ekkora hatással vannak az emberiségre?

Persze a magyarázatot korábban, még a növényeknél kell kezdenünk.

\footnotetext{
${ }^{3}$ Siebert 1986. 172.

${ }^{4}$ Jankovics 1991. 139.

${ }^{5}$ Guzsik 2000.
} 
A növények az emberiség kultúrtörténetében kiemelkedő szerepet töltenek be. Védelmet nyújtanak, táplálnak, oltják szomjunkat, gyógyító szerekkel betegséget űznek, bódító anyagaik feszültséget, gátlást oldanak, mérgeik pedig halált hoznak. Gyümölcseiket, magvukat „önként”, pusztulásuk nélkül adják, de életük árán is hasznosítjuk tüzelő- vagy építőanyagként őket.

Gyakran többet jelentenek önmaguknál, szimbolikus jelentéssel bírnak. ${ }^{6}$ Utalhatnak a bennünket körülvevő természeti környezetre, de a világ teljességére is vonatkozhatnak, sőt, kultúrnövények, ültetvények jelképezhetik a természetet átformálni igyekvő emberi akaratot is. Kifejezhetnek elvont fogalmakat és tulajdonságokat is, s ezt olyan magától értetődően teszik, hogy a köznyelv ma is virágnyelven beszélőnek nevezi azt, aki átvitt értelmű szavakat használ.

A növények közül is elsősorban a fák a legösszetettebb jelentésü, egyetemes szimbólumok. Hatalmas méretük, viharokkal is dacoló életerejük és pusztulásukig tartó szüntelen növekedésük az életet, tavaszi virágba borulásuk pedig az örök újjászületést jelképezik. Hosszú élettartamuk, valamint az évszakok váltakozásának redjéhez igazodó természetük pedig a kétarcú - ismétlődő, de visszafordíthatatlan - idő szimbóluma. ${ }^{7}$

Gyakran istenek szülő-, illetve lakóhelye, esetleg magának valamely istennek (pl. az egyiptomi Nut istennő) növényi megtestesülése is egy jeles fa. ${ }^{8}$ Jelképezheti magát az egész világot is, amennyiben annak lényegét mutatja, mint világtengely. Számos nép mítoszaiban szerepel egy kiemelkedő helyen - a saját világuk középpontjában - álló, hatalmas fa, mely egyrész kifejezi, másrészt rendszerbe fogja a világot. Gyökereit a mélybe ereszti, lombkoronája pedig az égbe nyúlik, ezáltal függőleges értelemben három részre osztja és egyben összeköti a világegyetemet. Ezzel utal a világ mitológiai fölépítésére (alvilág, a mi világunk, túlvilág), de az idő hármas tagolódására (múlt, jelen, jövő) is. Vízszintes értelemben mint igazodási pont rendszerezi a világot, négy részre (égtájra) osztva azt. ${ }^{9}$

Természetesen az egyetemes jelképi tartalom az éghajlattól, a természeti környezettől függően népenként más és más, de meghatározható fafajhoz kötődött. Ezek közül azokat a területeket kell feltétlenül áttekintenünk, melyek kapcsolatban állhattak a Megváltó szenvedésének történetével.

\footnotetext{
${ }^{6}$ A növényi szimbolikával több kutató is foglalkozik, közülük elsősorban Hoppál Mihály és Jankovics Marcell neve méltó az említésre, de érinti a témát több más szerző is. Fontana 1995, Hoppál-Jankovics 1990, Jankovics 1988, 1991, Siebert 1986, Tokarev 1988.

${ }^{7}$ Tokarev 1988. 57-59.

${ }^{8}$ Jankovics 1991. 25.

${ }^{9}$ Hoppál-Jankovics 1990. 60-62.
} 


\section{EGYIPTOM}

Az egyiptomi kultúra többezer éves virágzása során mindvégig szorosan kötődött a Nílushoz, igazodott annak természetéhez. A folyó gazdag növény- és állatvilágot táplált, közlekedési útvonalként összekötötte az ország távoli területeit, ugyanakkor a folyó két oldalát el is választotta egymástól. Évenként visszatérő áradása biztosította az emberi életet és annak ritmusát is. A müvelhető termőföld azonban csupán egy keskeny partmenti sávra terjedhetett ki, a többi, hatalmas területet a sivatag foglalta magába.

Ebben a mostoha természeti környezetben fokozott ereje volt az élet és a víz kapcsolatának. Az egyiptomiak ideális világa, menyországa vízjárta, mocsaras hely volt, gazdag növény- és állatvilággal, állandóan művelhető, kövér termőföldekkel.

Ennek a világnak számos növényi szimbóluma volt. Legelső is ezek közül a lótusz, ez a mocsárban élő virágos növény. Az egyik teremtésmítosz szerint Ré, a napisten egy, a mocsárból kihajtó lótuszvirág kelyhében született. ${ }^{10}$ Túl azon, hogy a lótusz virágjának alakja a női nemi szervre hasonlít, a virág és a nap közötti kapcsolat Plinius Secundus szerint abból adódik, hogy a lótusz kelyhe napkeltekor kinyílik, napnyugtakor becsukódik, így mutatva azonos ritmust a nap járásával. ${ }^{11}$ Más kutatók egyetemesebb és mélyebb kapcsolatot föltételezve a lótusz virágjában a szellemi létezésre ébredő anyag jelképét látják, amikor az az iszapból a zavaros víz homályán áttöri magát, hogy a fényben pompázzék. ${ }^{12}$

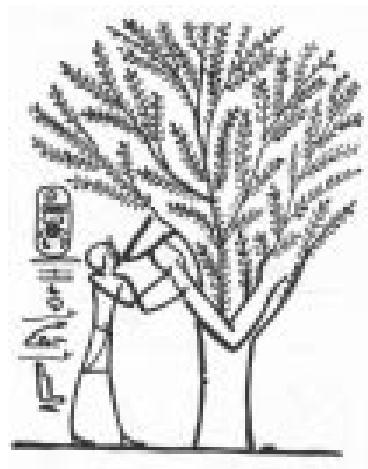

A fáraót tápláló szikomorfa (Skira, 1954. 38.)

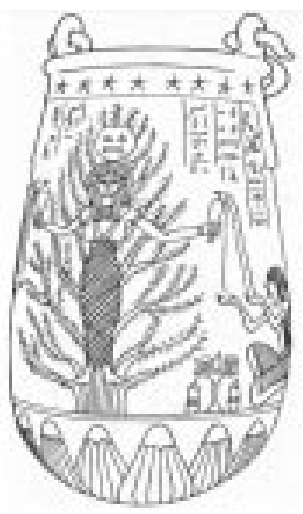

Nut istennő mint életfa (Jankovics, 1991. 8. kép)

\footnotetext{
${ }^{10}$ Tokarev 1988. I. 442.

${ }^{11}$ Plinius 1987. 32.

${ }^{12}$ Tokarev 1988. I. 170.
} 
Az egyiptomi mitológia legelőkelőbb fája a szikomorfa, vagy szikomorfüge (ficus sycomorus), mely gazdag és tápláló gyümölcseivel, törzséből szivárgó tejszerű nedvével és terebélyes, árnyékot, védelmet adó lombkoronájával a „csillagok hatalmas anyja”, az ,istenek szülője”, Nut istennő növényi megtestesülése, akit gyakran fa képében, az élet vizét öntözve, esetleg a fáraót szoptatva ábrázoltak. $^{13}$

Az idő, az évenkénti ismétlődés fája a datolyapálma (Phoinix dactylifera), a fák királynője. Ez a hatalmas termetü, 20-30 méter magasra is megnövő, hosszú életủ, rendkívül szívós, akár sós, tengerparti talajon is megélő növény elsősorban az emberéhez sokban hasonlító természetével vívta ki a tiszteletet. Ugyanis kétlaki, ráadásul természetes körülmények között bizonytalanul szaporodik, ezért mesterséges szaporítást igényel, melyet minden évben meghatározott időben és módon kell elvégezni. ${ }^{14}$ Ezt házassági szertartás során, örömünneppel egybekötve végezték el. Plinius Secundus szerint a nő pálmák csoportokban veszik körül a hím növényt, legszebb leveleikket fordulva felé. Ha a hím elpusztul, az özvegységre jutott pálmák többé nem szaporodnak. ${ }^{15}$ A pálmát is ábrázolták anyaistenként, amint a kezében tertott kancsóból az élet vizét öntözi. ${ }^{16}$

Egyiptomban kiemelkedő szerep jutott az elvont ábrázolásoknak. Ezek közül számtalan épített, faragott festett jelkép utal közvetlenül is a Jaru-földre, az egyiptomi menyországra, melybe előbb csak a fáraók, később minden egyiptomi bejuthatott. ${ }^{17}$ Erre, a keleti égben lévő túlvilágra a dús vegetáció, a kövér, állandóan művelhető földek, a gazdag állatvilág és a gondtalanság jellemző. Ennek a túlvilágnak földi kapui a templomok, melyekben kőbe faragva található meg a dús vegetáció, illetve a kertábrázolások, ahol szintén az ideálképekkel találkozunk.

\section{MEZOPOTÁMIA}

Ezen a területen, elsősorban az Asszír birodalomban (i. e. 19-7. sz.) virágzott a növények tisztelete. Kivételes szerepe a Datolyapálmának volt, ${ }^{18}$ amit egyértelmúem életfának tekintettek. Gyakran ábrázolják ezeket domborműveken, ahol az életfa az asszír világ tér-idő modellje is egyben, melyet afféle öröknaptárként is használtak, rögzítve rajta a hét napjait és az akkor ismert hét bolygót, valamint a holdhónapok 28 napos ciklusait. ${ }^{19}$

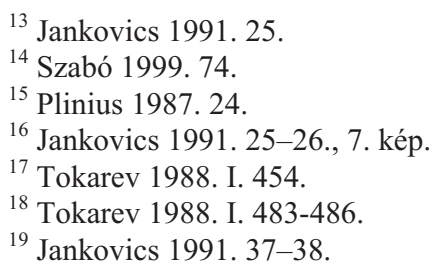




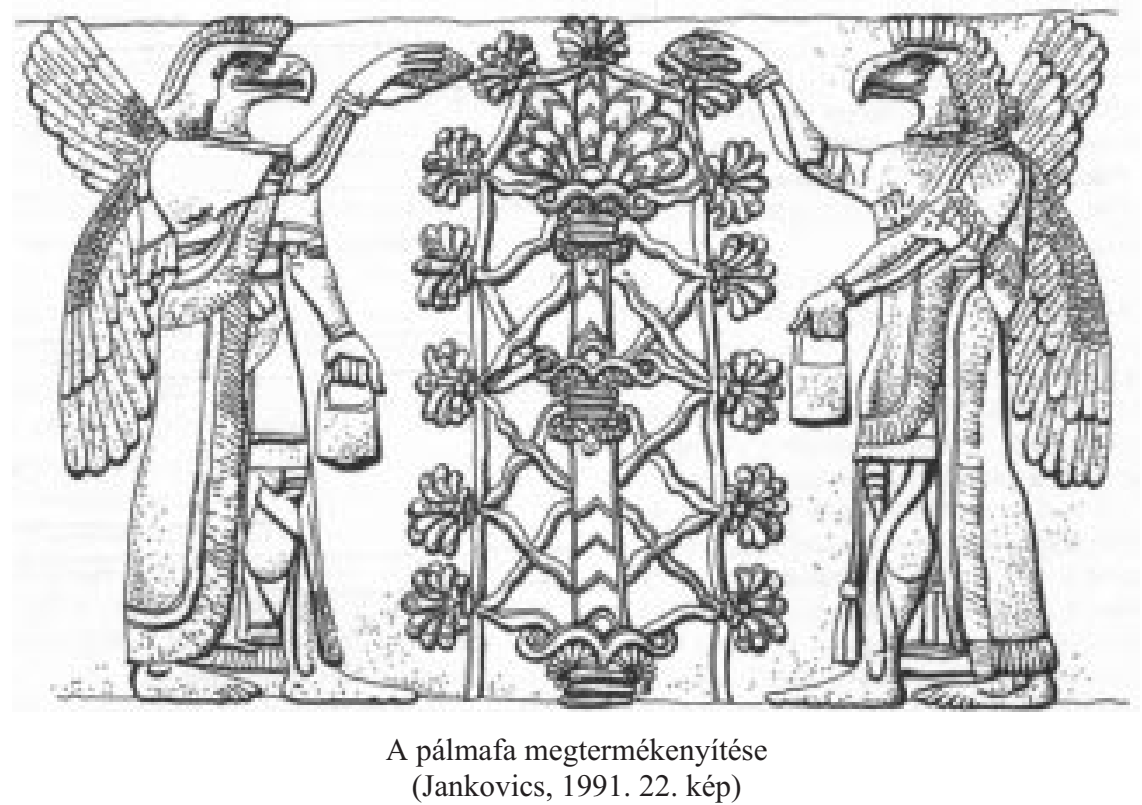

A British Múzeum több, Nimrudból elszármazott alabástrom reliefet őriz, melyek egykor II. Assurbanipal palotáját díszítették. ${ }^{20}$ Ezek egyikén egy megtermékenyítési jelenet látható, amelyet a korábban Egyiptom kapcsán már említett összeházasítási szertartás során szárnyas démonok végeznek el.

Mezopotámia területéről, Babilonból, Ninivéből számtalan növényt, elsősorban pálmát, de többször más, nehezebben azonosítható fát - talán cédrust - ábrázoló faragvány került elő. Közülük a figyelmemet leginkább egy - sajnos grafikai okokból nem bemutatható - elefántcsont töredék keltette föl. Ezen két virágzó, stilizált fa között egy istenalak áll, kezében pálmalevél köteggel, körülötte, egy négyzet sarokpontjain korsók vannak, s ezekbe a négyzet átlói mentén az isten szíve tájáról négy patak folyik. ${ }^{21}$ Mintha a Biblia Paradicsomi kertjének leírása elevenedne meg ezen a remekmúvön, ennek az emberi kultúra tudattalanul meglévő közös, ősi gyökereiből eredő párhuzamnak az igazolása azonban további kutatómunkát igényel.

\footnotetext{
${ }^{20}$ Moortgat 1967. 257-258. kép.

${ }^{21}$ Moortgat 1967. 243. kép.
} 


\section{A FÖLDKÖZI TENGER KÖRNYÉKE}

A közel-keleten több jeles fafajt is ismerünk, az ezek által hordozott jelentés azonban korántsem olyan egyértelmű, mint Egyiptom esetében.

Legkorábban minden bizonnyal a füge (Ficus carica) tisztelete terjedt el, hiszen ezt régészeti ásatások tanúsága szerint a mai Izrael területén már hétezer évvel ezelőtt is termesztették. ${ }^{22}$

Libanon területén minden bizonnyal a cédrusfát illette meg kiemelt tisztelet, melynek hatásai ma is érezhetőek.

Az élet fája azonban a Földközi tenger mentén a datolyapálma volt, melyet az a hasonlóság igazolhat, mely a fa latín neve (Phoinix), illetve a legendás ország, Főnicia, és a Főnix, az örökkévalóság madarának neve között egyértelmúen fölfedezhető. ${ }^{23}$

\section{ÓSZÖVETSÉG}

A Biblia mindkét könyve gazdag tárháza a növényi jelképeknek. Legelsőnek is említsük meg a Paradicsom kertjét, ahol két jeles fa: az élet fája, valamint a tiltott tudás fája található. Maga az Éden szó sumér eredetű, és öntözött földet, míg a Paradicsom óperzsa, $\mathrm{s}$ körülkerített földet jelent. ${ }^{24}$

„,És ültete az Úr Isten egy kertet Édenben, napkelet felöl, és abba helyezteté az embert, akit formált vala.

És nevele az Úr Isten mindenféle fát, tekintetre kedvest és eledelre jót, az élet fáját is, a kertnek közepette, és a jó és gonosz tudásának fáját.

Folyóvíz jö vala perdig Édenböl a kert megöntözésére; és onnét elágazik és négy föágra szakad vala."

(1Móz 2,8-10)

Az idézetben az életfa tipikus leírását olvashatjuk. A világ közepén áll, tövéből négy irányban négy folyó fakad. A mellette álló fával, a tiltott tudás fájával azonban eddig nem találkoztunk. A korábbi kultúrákban az emberi sors jórészt az istenek szeszélyétől függött, ${ }^{25}$ a tiltott tudás megszerzésével elkövetett eredendő bün

\footnotetext{
22 Jankovics 1991. 78.

${ }^{23}$ Hoppál-Jankovics 1990. 71.

${ }^{24}$ Jankovics 1991. 76.

${ }^{25}$ Tokarev 1988. I. 483-486.
} 
mint az emberiség szenvedésének legfőbb oka az Ószövetségben jelent meg első alkalommal. Arról nem értesülünk, hogy milyen fafajokról lehet szó, sőt azt sem tudjuk, egyátalán két külön fáról van-e szó, vagy pedig a más mítoszokban előforduló kéttörzsű fával kell számolnunk. ${ }^{26}$ Mindössze annyi bizonyos, hogy a bünbeesett emberpár közelében egy fügefa is állt:

„És megnyilatkozának mindkettőjöknek szemei és észrevevék, hogy mezitelenek; figefa levelet akgatának azért össze, és körülkötöket csinálának maguknak."

(1Móz 3,7)

A datolyapálma az Ószövetségben is fontos szerepet kapott. Dávid király háza ősanyjaként tisztelte, de pálmafa alatt közölte jóslatait Debóra prófétanő is.

„És ö a Debora-pálmája alatt lakott Ráma és Béthel között, az Efraim hegyén, és ide jöttek fel hozzá az Izráel fiai törvényre."

(Bírák 4,5)

Nyilvánvaló, hogy ezekben az esetekben egy pontosan meghatározott fafaj nem hitelesíti, konkretizálja az eseményeket, hanem a világmindenségre utal, ami egy uralkodó dinasztia, vagy egy kinyilatkozó - ha úgy tetszik, az Isten szavait közvetítő - jósnő esetében magától értetődő.

Fontos szerephez jutott a datolyapálma a szentély építésénél is, ahol a szentek szentjében a falat és kaput borító aranylemezekre került a képe.

„És a ház összes falain köröskörül kívül és belül Kérubokat, pálmafákat és kinyilt virágokat metszetett ki."

$(1$ Kir 6,29$)$

A szentély építésénél még két, eddig nem említett növény kapott szerepet: a cédrusfa és a gránátalma. A cédrusfa, Libanon címerfája a Bibliában egyrészt az örök élet és a paradicsom jelképe, másrészt az erő és a szépség allegóriája.

„Tekintete Libanon, páratlan cédrusfa."

(Énekekéneke 5,15)

${ }^{26}$ Jankovics 1991. 141. 
A szentély nagyobbrészt cédrusfából épült, díszítése pedig leginkább gránátalmával történt.

„Az egyik oszlop magassága tizennyolc sing volt, és egy rézgömb volt rajta [...] a gömbön köröskörül hálózat és gránátalmák mind ércböl."

$(2 \operatorname{Kir} 25,17)$

A gránátalma (Punica granatum) általánosan elterjedt termékenységszimbólum, mint a sokmagvú gyümölcsök (a gránátalma esetében 400-800 mag gyümölcsönként) általában. ${ }^{27} \mathrm{~A}$ zsidóknál különös tiszteletnek örvendett, melynek oka a hagyomány szerint a tisztasága volt. Kemény burkolata a legtöbb kórokozó elől megvédte a termés belsejét, amelyben rengeteg, vércsepp alakú, húsos mag volt. Később ezen adottságai miatt a szeplőtelen fogantatás jelképévé vált.

Fontos növény a szőlő is, mely szintén az élet, a termékenység és a gazdagság jelképe volt, s mint ilyen, életfa-funkciót is betölthetett. A Kánaánt felderítők egy hatalmas szőlőfürttel, gránátalmával és fügével tértek vissza, ezekkel a termésekkel - és jelképekkel - igazolva az Ígéret földjének gazdagaságát.

\section{ÚJSZÖVETSÉG}

Az Újszövetség szintén gazdag a növényi jelképekben, melyek a keresztény mitológiában betöltött szerepükkel és részben átformált jelentésükkel összegzik mindazt, amit eddig a növényekről elmondtunk.

Kezdjük mindjárt a kerttel. A kert - legyen az bármilyen - legelőször is az ember által birtokba vett természet jelképe. Korábban a növények léte teljes egészében a természettől, pontosabban a Teremtőtől függött. Az ő helyébe lépőnek képzelte magát az ember azáltal, hogy saját maga ültette, gondozta a környezetében lévő fákat, virágokat, mintha az őt körülvevő világot maga teremtette volna. Ennek a folyamatnak későbbi állomásaként a telepített berkeket, ligeteket kertek váltják fel, többnyire szabályos, leginkább négyzet alaprajzzal. Ez a forma egyértelmúen a mennybéli tökéletes világ földi megfelelője, ezáltal a kert a paradicsom földi mása lett. Ezt talán legszebben Lippai János fogalmazta meg:

„Az emberi itéletnek megfeddö sorsát elkerüli az, aki az egeket mennyei kerteknek; és a kerteket földi egeknek nevezi.

${ }^{27}$ Hoppál-Jankovics 1990. 75-76., Jankovics 1991. 84-85., Siebert 1986. 107., Szabó 1999. $100-102$. 
Mivel amennyire az alacsony föld a magas éggel föltehet: és földi szépségét az égi ékességgel egybevetheti: amint az Egek mennyei Paradicsomnak irigység nélkül neveztetnek, úgy kevélység nélkül a kertek földi egeknek. [...] Ami a mennyekben az egek alkotása, az a földön a kertek plántálása."

(Lippai János: Posoni kert) $)^{28}$

Ebben az értelemben jelennek meg szabályos alaprajzú kertek egyiptomi falképeken, királyi paloták tervein, de a keresztény kultúrát is megérintik, s kézzelfogható másolatokként minden kolostor udvarában megépülnek. A magyar nyelv az égi és a földi paradicsomi kertek közti szoros kapcsolatot pontosan jelzi a kolostorudvart körülvevő folyosó nevével. Azt ugyanis annak ellenére, hogy négyzetes teret vesz körül, kerengőnek mondja, kifejezve a mennybéli tökéletes és örökkévaló kör alak földi, négyzetben való tökéletlen megformálását.

A világot jelképező kertek ekképpen négyszög alaprajzúak, szimmetrikus elrendezésủek, közepükön az életfa áll - általában egy örökzöld növény, a Sankt Gallen-i ideálterven például savina, azaz nehézszagú boróka ${ }^{29}$-, a tövéből pedig a négy égtájat jelképező négy út vagy patak ered. Ezek a kertek legtöbbször magas fallal vannak körülvéve, védelmezve a belsőt a külvilágtól eszmeileg és gyakorlati szempontból egyaránt. Maga az óperzsa eredetü Paradicsom szó is körülkerített földet jelent. Az illetéktelen behatolók ellen védett mennyei kert további szimbólikus jelentéssel gazdagítja a keresztény mitológiát, ugyanis - hasonlóan a csonthéjas gyümölcsökhöz - egyértelműen utal a szeplőtelen fogantatásra, s ezáltal Szűz Máriára.

A paradicsomi kertben - részben megváltoztatva a korábbi hagyományt, mely szerint a Földközi tenger vidékén az élet legfontosabb jelképe a datolyapálma az életfa fügefa formáját mutatja, míg a tiltott tudás fájának szerepét évszázadokig tartó folyamat során fokozatosan az almafa veszi át. Mindkét eset némi magyarázatra szorul.

A fügefa (Ficus carica) bizonyíthatóan a vizsgált terület legrégebbi kultúrnövénye, termesztésének hétezer éves nyomai is ismertek, ${ }^{30}$ így a termesztett növények közül mitikus beágyazottsága is a legmélyebb lehetett. Az alma és a tiltott tudás közötti kapcsolat ennél kissé összetettebb. Ha az alma termését keresztben kettévágjuk, láthatjuk, hogy magjai mindig ötszög formában, ötágú csillagként helyezkednek el. Az ötszög mind a kabbalisztikus zsidó, mind a keresztény okkult tudományban a beavatottság jelképe. Egyszerüen azért, mert ez a legegyszerübb

${ }^{28}$ Stirling 1966.

${ }^{29}$ Jankovics 1991. 110

${ }^{30}$ Jankovics 1991. 78. 
olyan síkidom, amelynek pontos szerkesztéséhez külön ismeretre volt szükség, a köré írható körből csak bonyolult módon lehetett származtatni. Erre azonban csak a beavatottak voltak képesek, akik a tudással rendelkeztek. Egyébként a reneszánsz idejéből ismertek olyan ábrázolások, melyek a széttárt karokkal és lábakkal álló embert is ötszögbe szerkesztették, finoman összekapcsolva a bűnbeesést és a tudást annak végtermékével, a tudatára ébredő emberrel.

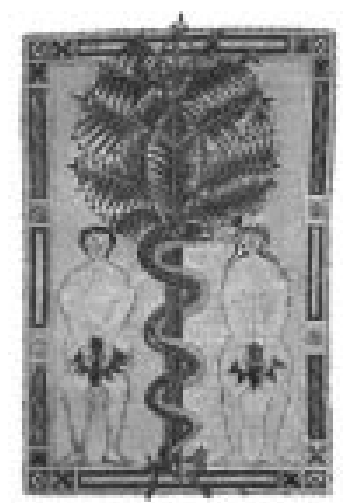

A tudás fája pálmafaként (Fontana, 1993. 103.)

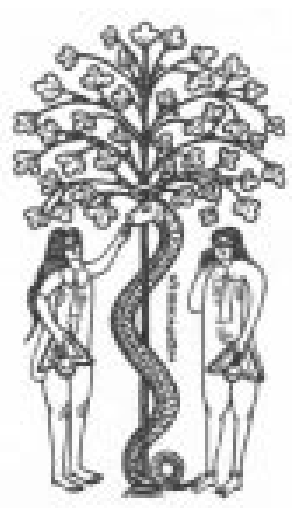

A tudás fája fügefaként (Siebert, 1986. 102.)

Jézus életét is számtalan növény, fa kíséri végig. A datolyapálma, bár a keresztény mitológia életfából a vértanúk jelképévé fokozza le, több esetben is megjelenik Jézus életében. Az Egyiptomba menekülő szent családot egy datolyapálma táplálja, s Virágvasárnapon, más néven Pálmák napján pálmaágakat terítenek a szamárháton Jeruzsálembe bevonuló Megváltó lábai elé. Ez a két eset a pálmafát egyértelműen életfa „,szerepben” mutatja be, s több korai ábrázolás szerint az ókeresztény ikonográfia még ekként is értelmezte. Később, a vértanúság ,intézményének" megjelenésével s a Jézussal szorosabban összefonódó növényi jelképek térhódításával szorul háttérbe és válik a világi hatalom előtt fejet nem hajtó mártírok attributumává.

Létezik két növény, mely nemcsak szerepel Jézus életének eseményeiben, hanem át is lényegül belé, illetve inkább a teremtő oldódik fel a növények által szimbolizált jelentésükben. Ez a két növény a szőlő és a gabona - búza vagy rozs. Mindkettő ősi, szinte minden kultúrkörben ismert élet- és termékenységjelkép.

Mindkét növény pusztulása árán teremt új életet. Az elvetett gabonaszem a földbe hullva elpusztul, hogy új, megsokszorozódott élet szülessen belőle, a szőlő pedig a présben hal meg, hogy halála árán új élet, bor - mely egyben a testnedvek, a vér jelképe - keletkezzék. Ezek a növények ezért olyan mitológiai hősökhöz kap- 
csolódnak, akik haláluk árán mentik meg a földi világot. Ilyen Ozírisz, akinek a gabona a jelképe, s Jézus, aki kimondottan mindkettővel azonosítja önmagát.

„Én vagyok az igazi szölötö, és az én atyám az igazi szölömüves."

(János 15,1)

„És minekutána a kenyeret vette, hálákat adván megszegé, és adá nékik, mondván: Ez az én testem, mely ti érettetek adatik: ezt cselekedjétek az én emlékezetemre.

Hasonlóképpen a pohárt is, minekutána vacsorált, ezt mondván: E pohár amaz új szövetség az én véremben, mely $t i$ érettetek kiontatik."

(Lukács 22,19-20)

Ezzekkel a motívumokkal tovább gazdagodik a keresztény mitológia jelképrendszere.

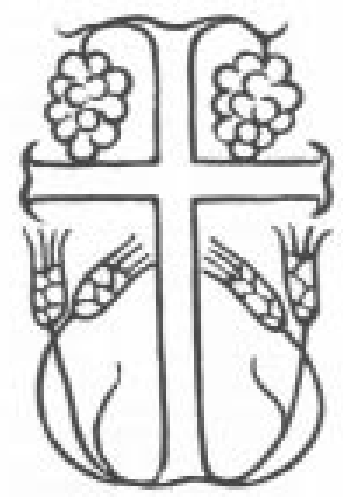

Kereszt szőlőtővel és kalásszal (Siebert, 1986. 296.)

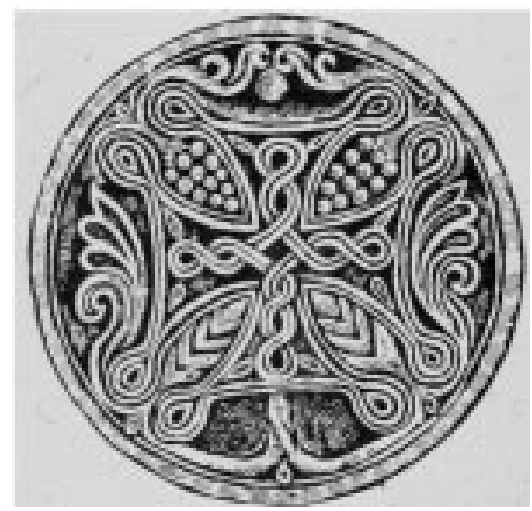

Örmény kereszt szőlővel és kalásszal (Oates, 1965. 63.)

Az egyik ábrázoláson Krisztus keresztfája köré szőlőindák tekerednek, előtte két ember pedig hatalmas szőlőfürtöt cipel. Ez a kép egyértelmú kapcsolatot ábrázol a kánaáni szőlöfürt és Krisztus kereszthalála között, vagyis: Krisztus kereszthalála tette lehetővé a földi paradicsom megtalálását. Ez a jelenet egyben azt is bemutatja, hogy miképpen alakul át a keresztfa durva és szégyenteljes kivégzőeszközből életfává, hiszen itt már a Kánaán közepén álló hatalmas szőlőtőkeként látjuk. 


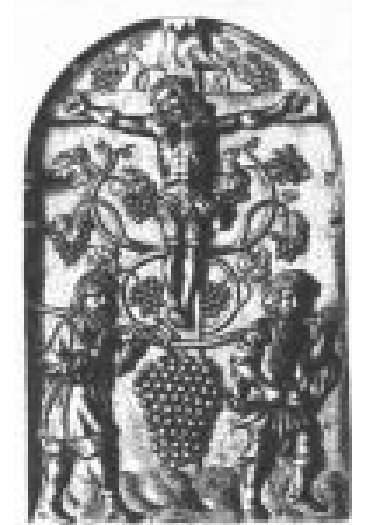

Krisztus keresztfája mint a kánaáni szőlőtő (Jankovics 1991. 138. 70. kép)

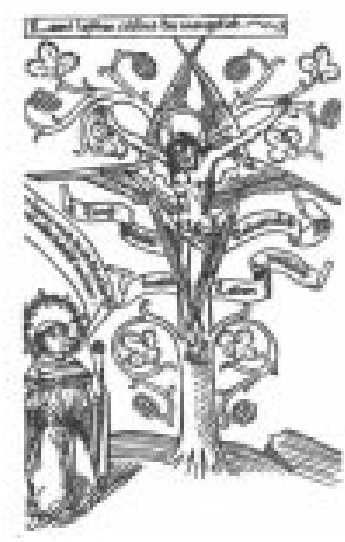

Heinrich Seuse látomása (Siebert 1986. 296.)

A legfontosabb fa azonban Krisztus keresztfája, amely megtöri a tiltott tudás fájának bünös hatását. Kísérletet is tettek a keresztfa feltalálása után (320. szeptember 14.) a legendát tovább terebélyesíteni azzal, hogy a keresztfa három, háromszögbe ültetett magból (pálma, cédrus és ciprus) eredt, amit Ábrahám utasítására Lót az Édenkertből hozott. Ezek egyesültek, a világfák világfáját alkotva, s ebből lett a keresztfa.

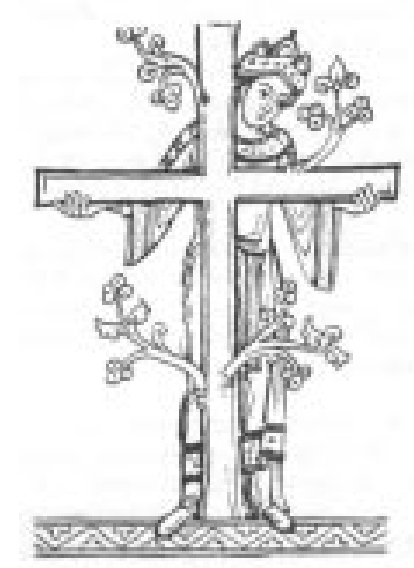

Ecclesia a kizöldült keresztfával (Siebert,1986. 92.)

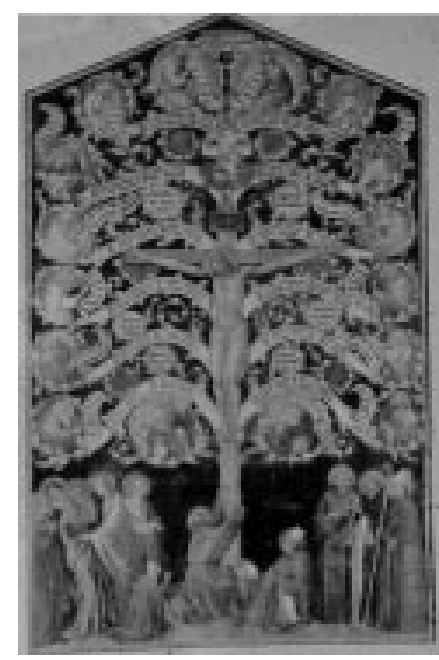

Taddeo Gaddi: A keresztfa mint családfa 
A keresztfa rendeltetésének szakralizálása több szempontból is értékelhető. Egyrész teljességgel érthető a szándék, mely más elemek hangsúlyozásával igyekszik a keresztfa szégyenteljes eredeti rendeltetését háttérbe szorítani. Az első századokban nem is alkalmazzák jelképként, mint azt Guzsik Tamás egy tanulmányában hangsúlyozza. ${ }^{31}$ A IV. század közepétől azonban megjelennek a kereszt kultuszának első hangsúlyos jelei, minden bizonnyal a föntiekben már érintett rendeltetésváltás következtében. Ennek a folyamatnak vezérgondolata volt a keresztfa életfává történő átlényegülése, amely a későbbiekben számos csodálatos képzőmúvészeti alkotás alapeszméjévé vált.

Ezzel rövid utazásunk véget ért. Nem jártuk be a teljes utat, nem érintettünk minden állomást - kihagytuk többek között a Jessze fájával kapcsolatos terjedelmes problémakört -, de talán érzékelhette a kedves olvasó, hogy a mitologikus ábrázolások - legyenek azok mítoszok vagy képzőmúvészeti alkotások - hány és hány jelentésrétegen átvergődve értelmezhetők igazán.

\section{IRODALOMJEGYZÉK}

Guzsik 2000

Hoppál-Jankovics 1990.

Jankovics 1991.

Moortgat 1967.

Oates 1965.

Plinius 1987.

Radocsay 1977.

Siebert 1986.

Skira 1954

Stirling 1996.

Szabó 1999.

Tokarev 1988.

${ }^{31}$ Guzsik 2000.
Guzsik Tamás: Szégyenfából megdicsőült jel. Budapest, BME 2000.

Hoppál Mihály-Jankovics Marcell-Nagy András-Szemadám György: Jelképtár. Budapest, Helikon 1990.

Jankovics Marcell: A fa mitológiája. Budapest, Csokonai 1991. Anton Moortgat: Die Kunst des Alten Mesopotamien. Köln, DuMont Schauberg 1967.

David Oates: The Dark Ages. London, Thames and Hudson 1965.

C. Plinius Secundus: A természet históriája. Budapest, Natura 1987.

Radocsay Dénes: Falképek a középkori Magyarországon. Budapest, Corvina 1977.

Jutta Siebert: A keresztény müvészet lexikona. Budapest, Corvina 1986.

Albert Skira: La peinture Égyptienne. Genf, 1954.

Stirling János: Magyar reneszánsz kertmüvészet a XVI-XVII. században. Budapest, Enciklopédia 1996.

Szabó Lajos: Trópusi-szubtrópusi gyümölcs-és élvezeti növények. Nyíregyháza, Stúdium 1999.

Sz. A. Tokarev: Mitológiai Enciklopédia I-II. köt. Budapest, Gondolat 1988. 


\section{THE HOLY CROSS AS THE TREE OF LIFE Summary}

Many marvellous wall paintings are on view in the medieval church of Zsegra. Several layers of later paintings have preserved these very important paintings. This is not a simple cross, but an alive tree with budding branches. It means not the appliance of execution; it is the Tree of Life, the sign of life itself.

The Tree of Life is one of the most frequent motifs in human culture whenever and wherever we see it. The Tree of Life, like the axle of the world, symbolically represents the whole world. Different trees personify the Tree of Life in different cultures: palm tree, oak tree, pine and fig tree. The most important two in the Christian culture are the palm tree and the vine stock. Plants and trees were very important in every day life, they served shelter, food, medicine. This is why it is a very popular symbol used in paintings. Plants and trees represent many different symbols of human life.

This essay was writen to bring attention to these symbols and help people to understand the importance of the Tree of Life.

Keywords: the holy cross, the tree of life, church of Zsegra 